\title{
Attitude to Distance Learning of Schoolchildren and Students: Subjective Assessments of Advantages and Disadvantages
}

\author{
Alla Belousova *D, Yuliya Mochalova and Yulya Tushnova (D) \\ Department of Educational Psychology and Organizational Psychology, Don State Technical University, \\ 344000 Rostov-on-Don, Russia; guliya@mail.ru (Y.M.); trubulya@yandex.ru (Y.T.) \\ * Correspondence: belousovaak@gmail.com
}

Citation: Belousova, A.; Mochalova, Y.; Tushnova, Y. Attitude to Distance Learning of Schoolchildren and Students: Subjective Assessments of Advantages and Disadvantages. Educ. Sci. 2022, 12, 46. https:// doi.org/10.3390/educsci12010046

Academic Editors: Neil Gordon and Peter Williams

Received: 29 November 2021

Accepted: 10 January 2022

Published: 14 January 2022

Publisher's Note: MDPI stays neutral with regard to jurisdictional claims in published maps and institutional affiliations.

Copyright: (C) 2022 by the authors. Licensee MDPI, Basel, Switzerland. This article is an open access article distributed under the terms and conditions of the Creative Commons Attribution (CC BY) license (https:// creativecommons.org/licenses/by/ $4.0 /)$.

\begin{abstract}
Currently, during the pandemic, the forced transition to distance learning carries a number of problems. These problems affect various aspects of education, including the study of students attitudes to distance learning. The purpose of this research is to study the features of the subjective attitude of schoolchildren and students to distance learning. This research involved 140 secondary school students (average age $\mathrm{M}=10.7, \mathrm{SD}=7.2(66.3 \% \mathrm{men})$ ) and 30 university students (average age $\mathrm{M}=22.5, \mathrm{SD}=2.4(20 \% \mathrm{men}))$. The methods used were a questionnaire, Chi-square test and Criterion $\varphi^{*}$. Fisher angular transformation. The study showed that schoolchildren do not intend to continue studying in the distance form if they choose, with a generally positive attitude towards distance learning. The self-assessment of motivation to study in a distance format has not changed, both among schoolchildren and students. Students are more likely to have a positive attitude to distance learning than schoolchildren. The variety of choices of advantages and disadvantages of distance learning is greater among students than among schoolchildren. The perspective of this study is thus to study the factors that determine the positive and negative attitudes to distance learning.
\end{abstract}

Keywords: distance learning; schoolchildren; students; attitude to distance learning

\section{Introduction}

Currently, global changes are taking place, largely as a result of the pandemic. This applies not only to the political, economic and social spheres of our life but also to the educational process in particular. The transition to online training has become a necessity, though distance learning, which has a close connection with rapidly developing computer technologies, has opened up promising prospects. However, the associated research and analysis of the literature show that there are certain contradictions in the very essence of the concept, as well as a number of shortcomings related to technology, teaching methods and the relationship between students and teachers.

Due to the sudden spread of coronavirus (COVID-19) and the consequent threat to people's lives, states were forced to adopt a system of measures aimed at preserving public health, in accordance with the recommendations of the World Health Organization [1]. In Russia, schools and universities have accordingly switched to distance learning. The emergency transfer of training to a distance format under the conditions of a pandemic had significant differences from properly planned e-learning because it assumed the forced closure of universities and schools and a bar on students and teachers visiting them. It also involved the mandatory restriction of all citizens to their homes, with the possibility of visiting only a limited number of shops and pharmacies located nearby, as well as the observance of social distancing measures [1].

According to the Federal Law on Education in Russia, "electronic learning", which consequently came into play, refers to the organization of educational activities with the use of the information contained in databases and used in the implementation of educational programs. This necessitated the use of information technologies, as well as information 
and telecommunication networks enabling the transmission of this information through communication lines: namely, the interaction of students and teaching staff.

Thus distance educational technologies are understood as being implemented mainly through information and telecommunication networks and involving the indirect (i.e., distance) interaction of students and teaching staff [2].

\section{Literature Review}

The history of distance learning includes a wide variety of educational environments, forms and methods of knowledge transfer and mastering, and many definitions have been proposed in the modern literature. Greenberg [3] defines modern distance learning as a "planned teaching/learning experience that uses a wide spectrum of technologies to reach learners at a distance and is designed to encourage learner-interaction and certification of learning" (p. 36). Tister and Blizner [4] stated that the term "has been applied to many instructional methods: however, its primary distinction is that the teacher and the learner are separate in space and possibly time" (p. 741).

Keegan [5] provided the most complete definition, underlining that distance education and training are the results of the technological separation of teacher and student, which relieves the student of the need to travel to "a fixed place, at a fixed time, to meet a fixed person, in order to be trained". According to [6], distance learning is a process of interactive communication between teacher and student. Andreev and Soldatkin [7] provided the following definition: "distance-learning is a purposeful process of interactive interaction of teachers and students with each other and with learning tools, invariant (indifferent) to their location in space and time, which is implemented in a specific didactic system." Thus, we can conclude that under these conditions, the teacher and the student are separated by space, though not always by time, and communication takes place through interactive technologies.

The convenience in terms of time and space that distance learning provides makes it most accessible and attractive to modern schoolchildren and students. However, despite the obvious advantages, there are a number of problems that need to be addressed. These include hidden costs, misuse of technology and the attitude of teachers, students and administration. Each of these problems affects the overall quality of distance learning as a product.

The quality of training largely depends on the attitude of the teacher. Studies by Inman and Kerwin [8] showed that teachers have a contradictory attitude to working remotely, with most of them rating the quality of education as average or low. They attribute this to the fact that many teaching staff do not use modern interactive technologies when developing and conducting courses, a refusal explained by the fact that the development of such materials takes a substantial amount of time, unremunerated by the top management. However, in the work of Narbut et al. [9], it was shown that teachers recognize the need to introduce online technologies into the educational process, with half having no categorical objections to this new training format.

Sherritt [10], in a survey of higher education leaders, noted that many consider distance-learning programs as secondary, a "necessary but deficient form of education" (p. 2). They are dissatisfied with the poor working conditions and isolation, as well as personal and professional hardships. Such an attitude hardly contributes to the creation of an effective learning environment for students.

As for students, distance learning is not suitable for all of them, nor are all disciplines well-taught through this format. Pleshakov and Sklyarova [11] commented that, depending on the ability of the students and teachers to organize the process remotely and indeed to understand the spirit of the enterprise, the student finds themself immersed either in the actual educational activity or in a pale imitation. Most likely to succeed with it are mature students, often possessing essential characteristics a tolerance for ambiguity, an understanding of the need for autonomy and the ability to be flexible [12]. Hardy and Boaz found that "compared to most face-to-face learning environments, distance- 
learning requires students to be more focused, better time managers and to be able to work independently and with group members" (p. 43). Many distance-learning students differ from traditional undergraduate students in that they already work in their specialty, have clearly defined goals and are more motivated [13]. Undergraduates also need the attention of teachers: in situations where face-to-face communication and intimacy are limited, students cannot be disciplined or supported through eye contact and body language [14]. It has long been known in psychology that students need to receive gnostic emotions and motivation to ensure thinking and intelligence [15].

The development of distance learning has become one of the main thrusts in the field of education: especially relevant at present when the world is experiencing a pandemic. One of its biggest advantages is the independence from time and place. Goncalves and Souza [16] showed with the example of Portuguese students that, in general, students are satisfied with the online format to a sufficient extent. Difficulties arise only with the organization of practical (laboratory) work. Other than this, one can study (or teach) at any time and place, thus creating bridges between different populations and cultures, which in turn enriches the exchange of information and knowledge [17]. Interviews with ADL (Asynchronous Distance Learning) students also showed that most students would like to have face-to-face training in addition to ADL, leading to the creation of a BL (blended learning) environment [18]. Petko et al. [19] concluded that students' ideas about the effective use of ICT are most predominant in teaching mathematics, literature and natural sciences.

The research also shows that students are interested in using digital technologies in teaching [20]. In order to extend the role of education, teachers are beginning to use nontraditional tools [21]. Wan et al. [22] found that the previous experience of working with ICT and virtual competence are two significant factors influencing distance learning and have a positive impact on its results. Yashina, Goreva [23] and Murzina [24] emphasized the importance of training competent specialists who are able to study independently, work with information and improve professional skills in the field of information technology. Moreover, the results of the study by Almazova et al. [25] showed that the problems faced by university teachers are as follows: the level of computer literacy, the electronic environment and support of the university, and the readiness of the teaching staff and the readiness of students for online learning, the latter two being the most important obstacles.

Part of the research on distance learning was aimed at analyzing the factors contributing to its effectiveness, with the study by Manochehr [26] finding that students with an assimilating or convergent learning style achieve better results in distance learning. Gomez et al. [27] studied which activities can be used to support different learning styles in this field. Research by [28,29] also showed that student characteristics and their social intelligence could play a big role in learning outcomes.

Even in the study of Salamon [30], it was shown that the technological aspect of the learning process is the least significant since technological tools develop over time and solutions to various problems and difficulties are introduced. The authors of [31-36] noted that the support and encouragement of students in the process of distance learning, together with the level of interaction between the teacher and the student, can influence effectiveness here. Miller et al. [37] conducted in-depth interviews among university teachers and found that they consider it important to be physically present in one learning space. Here, emotional and social connections are formed, which, in turn, positively affects the effectiveness of teaching and learning. The researchers conclude that the suitability of online learning varies for each type of student.

An analysis of the literature shows that studies of the problem of remote education affect various aspects. Dubey and Pandey [38] outlined the general problems faced by higher education institutions in India and the possible measures that could be taken in the current situation to ensure continuous learning. They also discuss the need for a "Paradigm shift in thinking" among students to adopt digital education rapidly. Samorodova et al. [39] noted a discrepancy between the ideas of teachers and their students regarding the effectiveness 
of certain forms of online education while studying the effectiveness of communicative methods of online learning. The problems of student motivation and students' attitudes to distance learning are considered in the works of Smith et al. [40], Abu-Khalil et al. [41], Sagin [42], Kolesnikova et al. [43,44] and Ryabikina et al. [45].

Kolesnikova et al. [44] conducted a survey of medical university students, studying their attitude to distance learning. A positive attitude among a majority of students was noted, with the caveat that the quality of distance learning is often lower than the traditional kind.

Thus, the problems of distance learning affect various aspects of education, including the study of students' attitudes to this form of education.

Accordingly, the question has arisen of how schoolchildren and university students relate to distance learning, its various parts and components, and its technological and content factors. The search for an answer to this question has, indeed, become the basis of our research.

In connection with this, in 2021, we organized and conducted a study of attitudes to distance learning among students and schoolchildren. The purpose of the study was to ascertain the peculiarities of the subjective attitude of schoolchildren and students to distance learning and to determine their subjective assessments of the advantages and disadvantages of distance education.

In the article, there is an analysis of the publications on the stated problem. The results and the discussion of the study are also described.

\section{Materials and Methods}

One hundred and forty secondary school students took part in the study (average age $\mathrm{M}=10.7, \mathrm{SD}=7.2(66.3 \%$ men) $), 25.7 \%$ of them studying in middle classes (7-9 grade) and $74.3 \%$ of respondent's at high school (10-11 grade); 30 university students also participated in the study (average age $\mathrm{M}=22.5, \mathrm{SD}=2.4(20 \%$ men)).

The main method of research was by questionnaire, with two such developed by the author's team being used. Initially, the questionnaire "Attitude to distance-learning" was developed from 8 questions with a simple alternative answer. The following characteristics were studied: emotional attitude to distance learning, subjective assessment of the level of complexity of distance learning, subjective assessment of success in distance learning, time spent on independent work, availability of direct contact with the teacher, difficulties of distance learning and the willingness to continue learning remotely.

The questions therein were compiled on the basis of conversations with subject teachers from secondary school (teacher 1 had 7 years of teaching experience; teacher 2 had 11 years of teaching experience; teacher 3 had 15 years of teaching experience).

The questionnaire "Advantages and disadvantages of distance-learning" includes 52 closed-type questions, two of them with a simple alternative answer about the assessment of learning motivation and the level of academic load, with the remaining 50 questions assuming a dichotomous answer (selected/not selected). At the same time, 22 questions were devoted to the advantages of distance learning, and 28 to disadvantages: the prime focus in the questionnaire's creation.

The questionnaire questions were compiled based on an analysis of the advantages and disadvantages of distance learning [13,18-20,46].

The questionnaire procedure was conducted in person, in the same conditions for all respondents (audience, $1.5 \mathrm{~m}$ between the survey participants, identical forms and writing materials). The questionnaire form is group, blank. It offered respondents the chance to read the questions and choose the most appropriate answer, and the procedure was anonymous; it was conducted during the forced introduction of distance learning during the COVID-19 pandemic (2021). The transition to the remote method took place in waves, depending on the epidemiological situation in the region. Accordingly, the possibility of conducting a face-to-face questionnaire presented itself when changing the remote format to face-to-face. 
Distance learning, both for schoolchildren and students, was organized synchronously, without breaking the usual schedule, on the basis of Zoom, Google Meet, Skype, Discord and other services. The university also used the Moodle platform to create asynchronous e-learning courses. Secondary schools use the Moodle, Google Classroom platforms and digital educational platforms: Russian e-school, Mobile e-education, Teach. ru, Yandex.Textbook, Online school Foxford.ru, Yaklass.ru, 1C: School and others.

Informed voluntary consent was obtained from each of the participants included in the study.

The purpose of the study was formulated thus: to study the peculiarities of the subjective attitudes of schoolchildren and students to distance learning.

The research objectives were to analyze current research on the attitudes of schoolchildren and students to distance learning, consider the features of subjective attitudes to it amongst schoolchildren, describe the advantages and disadvantages of distance learning as voiced by schoolchildren and students and conduct a comparative analysis, and to compare the advantages and disadvantages of distance learning in the opinions of schoolchildren and students with attitudes to this form of education.

The statistical procedures used were the Chi-square test for comparing theoretical and empirical distributions, the Chi-square test for comparing several empirical distributions and Fisher angular transformation.

The assumptions tested were as follows:

Hypothesis 1 (H1). Various components of the subjective attitude to distance learning can be relied upon to be unequally distributed among schoolchildren.

Hypothesis 2 (H2). The level of self-assessment regarding motivation to study remotely, together with subjective assessment of the resulting academic load, can be distributed unequally in a group of schoolchildren and students. Moreover, the frequency distribution of the level of self-assessment of motivation and subjective assessment of academic load in distance learning can have significant differences in groups of schoolchildren and students.

Hypothesis 3 (H3). The attitude to distance learning (positive and negative) may be excellent in groups both of secondary school students and students.

Hypothesis 4 (H4). Schoolchildren and students may have different frequency distributions of advantages and disadvantages of distance learning.

Regarding the content of the assumptions put forward, it is necessary to indicate that the study was conducted in two stages. In the first stage, the questionnaire "Attitude to distance-learning" was used, given our assumption that subjective assessments of various aspects of distance learning of schoolchildren are not accidental. At the second stage of the study, an expanded questionnaire, "Advantages and disadvantages of distance-learning", was used, and a comparison group (students) was introduced. We assumed that the self-assessment of motivation to study, and the subjective assessment of the academic load, would vary both among schoolchildren and students. We also suggested that selfassessment of motivation and subjective assessment of the academic load may be different for schoolchildren and students since at the university, a large proportion of academic time is devoted to independent work.

Finally, we also assumed that schoolchildren would have a less positive attitude to distance learning and that subjective assessments of the advantages and disadvantages among schoolchildren and students would be fundamentally different.

\section{Results}

In the beginning, a questionnaire "Attitude to distance-learning" was conducted. The survey was attended by 60 students from the 11 th grade of secondary school (35\% men). The assumption that components of the subjective attitude to distance learning can reliably 
be unequally distributed among schoolchildren (Hypothesis 1) was tested using the Chisquare test for comparing theoretical and empirical distributions. It was established that the emotional attitude to distance learning, subjective assessment of the complexity of distance learning, subjective assessment of success in distance learning, time spent on independent work, availability of direct contact with the teacher, difficulties of distance learning and willingness to continue remotely learning are distributed unequally in the empirical group (Table 1).

Table 1. Distribution of components of subjective attitude to distance learning in a group of schoolchildren.

\begin{tabular}{|c|c|c|c|}
\hline $\begin{array}{c}\text { Indicators of Subjective Attitude to } \\
\text { Distance Learning }\end{array}$ & $\%$ Category & Chi-Square Test & $p$ \\
\hline $\begin{array}{l}\text { Subjective assessment of the level of complexity of } \\
\text { distance learning }\end{array}$ & “Easy” 100 & - & - \\
\hline Emotional attitude to distance learning & $\begin{array}{l}\text { "Like" } 90 \\
\text { "Dislike" } 10\end{array}$ & 38.4 & 0.000 \\
\hline Subjective assessment of success in distance & $\begin{array}{c}\text { "High"1.7 } \\
\text { "Average"98.3 }\end{array}$ & 56.067 & 0.000 \\
\hline Time spent on independent work & $\begin{array}{l}\text { "1 hour" } 88.3 \\
\text { "1-3 hours" } 10 \\
\text { "less than } 1 \text { hour" }\end{array}$ & 82.3 & 0.000 \\
\hline Availability of directcontact with the teacher & $\begin{array}{l}\text { "Available" } 98.3 \\
\text { "Little available" } 1.7\end{array}$ & 56.067 & 0.000 \\
\hline Difficulties of distancelearning & $\begin{array}{c}\text { "Lack of live communication with the teacher" } 50 \\
\text { "Lack of live communication with classmates" } 14.9 \\
\text { "Insufficient knowledge of computer technology" } 6.8 \\
\text { "Difficulties with time allocation" } 27.1 \\
\text { "No difficulties" } 1.4\end{array}$ & 52.267 & 0.000 \\
\hline Willingness to continue learning remotely & $\begin{array}{l}\text { "Ready" } 3.3 \\
\text { "Not ready" } 96.7\end{array}$ & 65.297 & 0.000 \\
\hline
\end{tabular}

The results of the first series of the study attracted attention with some contradictions. For example, most of the students have a positive attitude to distance learning (Table 1) but do not want to continue studying in this form voluntarily. Moreover, indicating the sufficiency of communication with the teacher, $50 \%$ of respondents call it a disadvantage, the same applies to difficulties with the allocation of time. Due to the revealed contradictory results, it was decided to create a new questionnaire studying the advantages and disadvantages of distance learning. At the next stage of the research, 80 pupils of secondary schools ( $33.8 \%$ men) and 30 students ( $20 \%$ men) were interviewed.

It was revealed (Chi-square test for comparing empirical and theoretical distributions) that the level of self-assessment of motivation for distance learning and the assessment of the academic load is distributed unequally (Hypothesis 2) in a group of schoolchildren and students (Table 2).

Considering the results, we can conclude that both schoolchildren and students are significantly more likely to note that motivation in the distance format did not change or increase (Table 2). At the same time, there are no statistically significant differences in the groups of schoolchildren and students in the assessment of motivation in distance learning (Chi-square test $=0.883, \mathrm{df}=3, p=0.829$ ).

The volume of the academic load, according to schoolchildren, did not change or increase, while according to students, it actually decreased (Table 2). There are significant differences in the assessment of the volume of academic load in distance learning for students and schoolchildren (Chi-square test $=18.786, \mathrm{df}=3, p=0.000$ ). 
Table 2. The level of motivation to study remotely and the assessment of the amount of academic load in a group of schoolchildren and students.

\begin{tabular}{ccc}
\hline Group/Statistics & Motivation & Workload Volume \\
\hline \multirow{3}{*}{ Schoolchildren } & Increased-15 & Increased-35 \\
& Decreased-32 & Decreased-15 \\
& Not changed-46 & Not changed-41 \\
& I don't know-6 & I don't know-8 \\
\hline Chi-square test $(p)$ & $30.7(0.000)$ & $23.3(0.000)$ \\
\hline \multirow{2}{*}{ Students } & Increased-16.7 & Increased-20 \\
& Decreased-23.3 & Decreased-50 \\
& Not changed-53.3 & Not changed-13.3 \\
& I don't know-6.7 & I don't know-16.7 \\
\hline Chi-square test $(p)$ & $14.533(0.002)$ & $10.267(0.016)$ \\
\hline
\end{tabular}

Next, we ranked the advantages and disadvantages of distance learning, which were outlined by schoolchildren (Table 3).

Table 3. Advantages and disadvantages of distance learning, according to schoolchildren.

\begin{tabular}{|c|c|c|c|}
\hline Advantages & $\%$ & Disadvantages & $\%$ \\
\hline \multirow[t]{2}{*}{ Reducing the chances of coronavirus infection } & \multirow[t]{2}{*}{81.25} & $\begin{array}{c}\text { The difficulty of performing practical tasks without } \\
\text { teacher explanations }\end{array}$ & 61.25 \\
\hline & & Replacing training with self-study & 53.75 \\
\hline $\begin{array}{c}\text { Better visibility of slides compared to } \\
\text { classroom lessons }\end{array}$ & 52.5 & Relatives may distract during classes & 43.75 \\
\hline Classes in comfortable home conditions & 46.25 & Eyesight load & 40 \\
\hline Comfort clothing & 41.25 & Interruptions with ZOOM platform (other platforms) & 38.75 \\
\hline Body position & 36.25 & Information is partially absorbed & 38.75 \\
\hline Absence of transport spending for independent study & 36.25 & $\begin{array}{l}\text { A large amount of information spent for } \\
\text { independent study }\end{array}$ & 37.5 \\
\hline Absence of communication with unpleasant people & 33.75 & Poor internet speed & 32.5 \\
\hline The training material remains available for download & 33.75 & Internet outages & 31.25 \\
\hline Between classes, you can do personal things & 31.25 & Bad feedback & 26.25 \\
\hline can do personal things & 27.5 & Insufficient knowledge studying of PC & 26.25 \\
\hline Economic benefit & 22.5 & Lack of "live communication" with classmates & 25 \\
\hline No fear of oral answers & 21.25 & No physical education classes & 25 \\
\hline No spending on lunch in the dining room or café & 20 & Power outage & 22.5 \\
\hline Stress reduction & 20 & The need to have internet access & 21.25 \\
\hline You can manage the time yourself & 18.75 & $\begin{array}{c}\text { Technical interruptions in the process of reproducing } \\
\text { the material }\end{array}$ & 20 \\
\hline There is time for self-development & 16.25 & Absence of "live communication with teachers & 18.75 \\
\hline Flexibility of the educational process & 11.25 & Boring and monotonous & 13.75 \\
\hline No fear of being late for classes & 8.75 & $\begin{array}{c}\text { There is no feedback in communication with } \\
\text { the teacher }\end{array}$ & 12.5 \\
\hline $\begin{array}{l}\text { The release of time resources and the ability to build a } \\
\text { schedule yourself }\end{array}$ & 8.75 & A large volume of specified materials & 11.25 \\
\hline Relaxed state & 7.5 & $\begin{array}{c}\text { Concentration on studying at home is not always } \\
\text { the case }\end{array}$ & 10 \\
\hline Fresh air & 2.5 & $\begin{array}{l}\text { There are few opportunities to study the material in } \\
\text { detail during the lesson }\end{array}$ & 8.75 \\
\hline The ability to combine work with study & 0 & $\begin{array}{l}\text { Untimely presentation of materials and assignments } \\
\text { by teachers }\end{array}$ & 7.5 \\
\hline & & $\begin{array}{c}\text { There is no feedback in communication } \\
\text { with classmates }\end{array}$ & 6.25 \\
\hline & & No one to ask questions & 5 \\
\hline & & $\begin{array}{l}\text { The need to listen to tedious speech with a text that is } \\
\text { already in the presentation }\end{array}$ & 1.25 \\
\hline & & Insufficient amount of educational material & 0 \\
\hline & & Insufficient knowledge of computer technology & 0 \\
\hline
\end{tabular}

Further, the selection of the advantages and disadvantages of the distance-learning form of students (Table 4) was ranked. 
Table 4. Advantages and disadvantages of distance learning, according to students.

\begin{tabular}{|c|c|c|c|}
\hline Advantages & $\%$ & Disadvantages & $\%$ \\
\hline Absence of transport spending & 90.00 & $\begin{array}{l}\text { Concentration on studying at home is not always } \\
\text { the case }\end{array}$ & 70.00 \\
\hline Reducing the chances of coronavirus infection & 70.00 & Lack of "live communication" with teachers & 66.67 \\
\hline The ability to combine work with study & 63.33 & $\begin{array}{c}\text { The difficulty of performing practical tasks without } \\
\text { teacher's explanations }\end{array}$ & 60.00 \\
\hline Between classes, you can do personal things & 53.33 & Relatives can distract you during classes & 60.00 \\
\hline Classes in comfortable home conditions & 50.00 & Internet interruptions & 53.33 \\
\hline Relaxed state & 50.00 & There is no one to ask questions & 53.33 \\
\hline Less study fatigue & 46.67 & Power outage & 50.00 \\
\hline Lack of fear of oral answers & 46.67 & Absence of "live communication" with classmates & 50.00 \\
\hline Economic benefit & 46.67 & The need to listen to tedious speech with a text & 50.00 \\
\hline No spending on lunch in the dining room or café & 46.67 & No feedback in communication with the teacher & 43.33 \\
\hline The training material remains available for download & 40.00 & $\begin{array}{c}\text { Interruptions with the ZOOM platform } \\
\text { (other platforms) }\end{array}$ & 36.67 \\
\hline Fresh air & 40.00 & Bad feedback & 36.67 \\
\hline Flexibility of the educational process & 36.67 & $\begin{array}{c}\text { There is no feedback in communication } \\
\text { with classmates }\end{array}$ & 36.67 \\
\hline Comfortable clothes & 36.67 & Insufficient knowledge of PC & 30.00 \\
\hline Body position & 36.67 & $\begin{array}{l}\text { Untimely presentation of materials and assignments } \\
\text { by teachers }\end{array}$ & 30.00 \\
\hline Stress Reduction & 33.33 & Boring and Monotonous & 30.00 \\
\hline $\begin{array}{l}\text { Release of time resources and the opportunity to build } \\
\text { a schedule yourself }\end{array}$ & 30.00 & No physical education classes & 30.00 \\
\hline Absence of communication with unpleasant people & 23.33 & The need to have internet access & 26.67 \\
\hline Absence of fear of being late for classes & 20.00 & $\begin{array}{l}\text { Technical interruptions in the process of } \\
\text { reproducing material }\end{array}$ & 26.67 \\
\hline Better visibility of slides compared to classroom classes & 20.00 & Poor internet speed & 23.33 \\
\hline There is time for self-development & 20.00 & Replacing training with self-study & 23.33 \\
\hline \multirow[t]{7}{*}{ You can manage the time } & 16.67 & A large volume of specified yourself materials & 16.67 \\
\hline & & $\begin{array}{l}\text { There are few opportunities to study the material in } \\
\text { detail during class }\end{array}$ & 13.33 \\
\hline & & Insufficient amount of educational material & 13.33 \\
\hline & & Visual load & 13.33 \\
\hline & & A large amount of information for self-study & 10.00 \\
\hline & & Insufficient knowledge of computer technology & 0.00 \\
\hline & & Information is partially absorbed & 0.00 \\
\hline
\end{tabular}

The ranking procedure made it possible to compare the priority advantages and disadvantages of distance learning in groups of students and schoolchildren. The common advantage is "reducing the chances of infection with coronavirus"; the disadvantage is "the difficulty of performing practical tasks without explanations from the teacher".

Further, the sample was divided into two groups with a positive and negative attitude to distance learning. The attitude to distance learning was determined by comparing the percentage of the selection of advantages and disadvantages to distance learning. Since the survey assumed multiple choices, the percentage of selected advantages and disadvantages was calculated. Respondents who chose, with significantly greater frequency, advantages rather than disadvantages were included in the group of respondents with a positive attitude to distance learning. The respondents that were significantly more likely to choose disadvantages were included in the group with a negative attitude to distance learning (Figure 1).

Using the Fisher angular transformation, it was found that students are significantly better at distance learning than schoolchildren $\left(\varphi^{*} \mathrm{emp}=2.588, p<0.01\right)$ (Hypothesis 3$)$.

Testing Hypothesis 4 (Chi-square test for comparing several empirical distributions, the Fisher angular transformation) showed that schoolchildren and students have a reliably excellent frequency distribution of some of the advantages to distance learning (Table 5). 


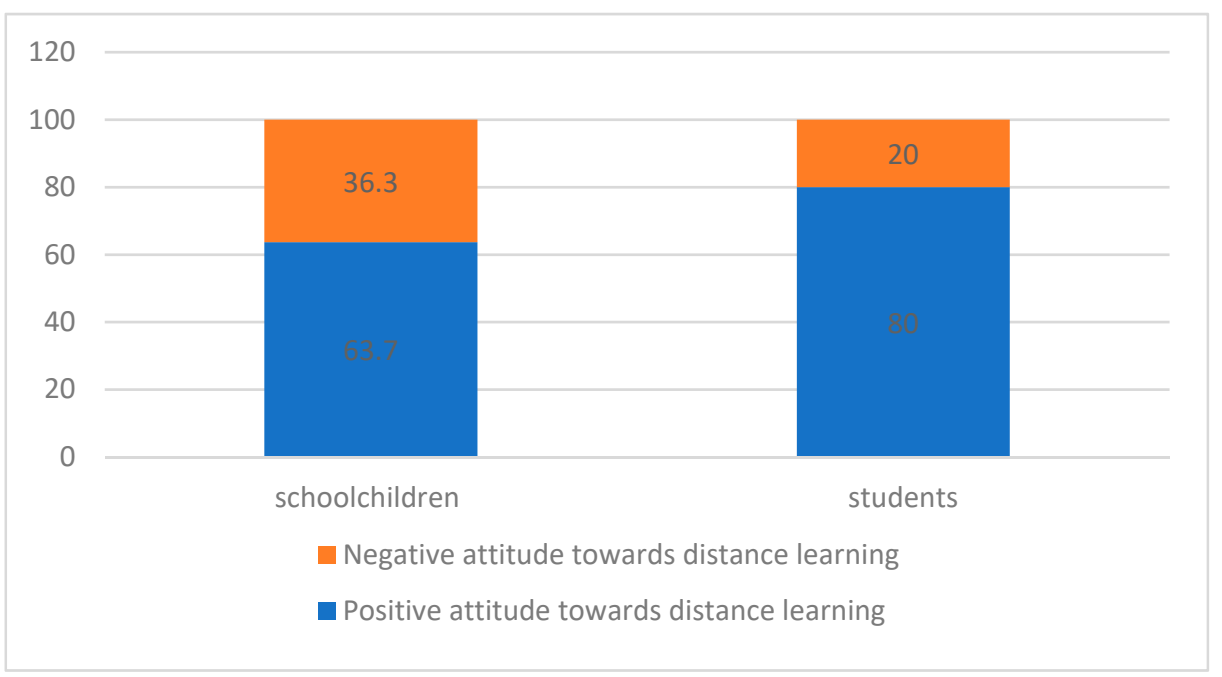

Figure 1. Distribution of students and schoolchildren with a negative and positive attitude to distance learning (in \%).

Table 5. Frequency distribution of advantages and disadvantages of distance learning in groups of schoolchildren and students.

\begin{tabular}{|c|c|c|c|}
\hline Advantage/Disadvantage & Schoolchildren (\%) & Students (\%) & Statistics \\
\hline Reduction in study fatigue & 27.5 & 46.7 & $\varphi^{*} \mathrm{emp}=2.835, p<0.01$ \\
\hline Better visibility of slides, graphic material & 52.5 & 20 & Chi-square test $=9.37, p=0.002$ \\
\hline No fear of oral answers & 21.2 & 46.7 & Chi-square test $=6.964, p=0.008$ \\
\hline Flexibility of the educational process & 11.2 & 36.7 & Chi-square test $=9.475, p=0.002$ \\
\hline Between classes, you can do personal things & 31.2 & 53.3 & $\varphi^{*} \mathrm{emp}=3.196, p<0.01$ \\
\hline The ability to independently build a schedule & 8.8 & 30 & Chi-square test $=7.926, p=0.005$ \\
\hline Ability to combine work with study & 0 & 63.3 & Chi-square test $=61.245, p=0.000$ \\
\hline Relaxed state & 7.5 & 50 & Chi-square test $=25.514, p=0.000$ \\
\hline Fresh air & 2.5 & 40 & Chi-square test $=27.623, p=0.000$ \\
\hline Economic benefit & 22.5 & 46.7 & Chi-square test $=6.177, p=0.013$ \\
\hline No transport costs & 36.2 & 90 & Chi-square test $=25.222, p=0.000$ \\
\hline No costs for lunch in the dining room & 20 & 46.7 & Chi-square test $=7.822, p=0.005$ \\
\hline Internet outages & 31.2 & 53.3 & Chi-square test $=4,551, p=0.033$ \\
\hline Power outage & 22.5 & 50 & Chi-square test $=7.587, p=0.005$ \\
\hline Insufficient amount of educational material & 0 & 13.3 & Chi-square test $=11.069, p=0.001$ \\
\hline $\begin{array}{l}\text { Untimely presentation of educational material by the } \\
\text { teacher }\end{array}$ & 7.5 & 30 & Chi-square test $=9.379, p=0.002$ \\
\hline Absence of "live communication" with the teacher & 18.8 & 66.7 & Chi-square test $=23.091, p=0.000$ \\
\hline Absence of "live communication" with classmates & 25 & 50 & Chi-square test $=6.286, p=0.012$ \\
\hline There is no feedback in communication with teacher & 12.5 & 43.3 & Chi-square test $=12.543, p=0.000$ \\
\hline $\begin{array}{c}\text { There is no feedback in communication with } \\
\text { classmates }\end{array}$ & 6.2 & 36.7 & Chi-square test $=16.24, p=0.0005$ \\
\hline $\begin{array}{l}\text { The need to listen to tedious speech, the content of } \\
\text { which repeats the text of the presentation }\end{array}$ & 1.2 & 50 & Chi-square test $=41.716, p=0.000$ \\
\hline There is no one to ask questions & 5 & 53.3 & Chi-square test $=34.263, p=0.000$ \\
\hline Replacing learning with self-learning & 53.8 & 23.3 & Chi-square test $=8.142, p=0.004$ \\
\hline Large amount of information for self-study & 37.5 & 10 & Chi-square test $=7.587, p=0.005$ \\
\hline Information is partially absorbed & 38.8 & 0 & Chi-square test $=16.187, p=0.000$ \\
\hline $\begin{array}{l}\text { Poor concentration on the learning process in home } \\
\text { conditions }\end{array}$ & 10 & 70 & Chi-square test $=40.46, p=0.000$ \\
\hline Visual load & 40 & 13.3 & Chi-square test $=7.047, p=0.008$ \\
\hline
\end{tabular}

Moreover, schoolchildren and students have a reliably distinct frequency distribution of some disadvantages to distance learning (Table 5). It should be noted that the number of distinct disadvantages of distance learning among students and schoolchildren exceeds the number of distinct advantages.

Thus, the formulated assumptions were partially or completely confirmed. This allows you to describe the content of the results obtained. 


\section{Discussion}

Studies of the subjective attitude of schoolchildren to distance learning showed that $100 \%$ of schoolchildren note the ease of distance learning, and $90 \%$ say that they like this method. At the same time, the majority of the empirical group (98.3\%) assesses the success of their educational activities with this method as average. Strangely, with the so-called ease of the distance method and the positive attitude of schoolchildren towards it, only $3.3 \%$ are ready to continue their education in distance form. That is, most schoolchildren accept distance learning as a necessity related to the prevention of the spread of a new coronavirus infection (COVID-19) and not as a preferred form of education.

Among the disadvantages of distance learning in the first series of the study, schoolchildren named the lack of live communication with the teacher, difficulties in time allocation, lack of live communication with classmates, insufficient knowledge of technology (given in descending order of the weight of the frequency of occurrence of the trait). A slightly different picture is revealed by the results of the study [45], which show that in distance learning, young people have more cognitive motives than social motives. There are also contradictions with other survey questions: for instance, $98.3 \%$ of schoolchildren note the availability of contact with the teacher, despite the fact that $50 \%$ of schoolchildren call the absence of direct communication with the teacher a difficulty. Here, though, we see that direct communication with the teacher is important for students. It is also contradictory that $88.3 \%$ of respondents spend $1 \mathrm{~h}$ performing independent work, but $27.1 \%$ call the "time allocation" a difficulty.

Schoolchildren are significantly more likely to note that the self-assessed motivation to study in a distance format has not changed and decreased, and the amount of academic load has not changed or increased. Students, on the other hand, coincide with schoolchildren in assessing motivation, but more often, they note that the academic load in the distance form has decreased.

Schoolchildren, more often, as advantages of distance learning, note a decrease in the chances of infection with coronavirus and better visibility of slides and graphic material $(>50 \%)$. The least significant advantages $(<10 \%)$ are identified by secondary school students as: absence of fear of being late, the release of time resources, relaxed state of mind and body, and fresh air. The opportunity to combine work with the study was not named as a virtue by any student.

The most significant disadvantages of distance learning, according to secondary school students, are $(>50 \%)$ the difficulty of performing practical tasks without explanations and replacing learning with self-study. The least significant disadvantages of distance learning are identified by schoolchildren $(<10 \%)$ as an insufficiently detailed study of the material in the lesson, untimely provision of materials for independent work, lack of feedback from classmates and decreased interest in the lesson due to monotony of speech. The items "insufficient amount of educational material" and "insufficient knowledge of computer technology" were not chosen by any student.

The results of the study showed that students more often note the advantages of distance learning $(>50 \%)$ as no transport costs, reduced chances of infection with coronavirus, the ability to combine study with work, the ability to perform personal tasks between classes, classes in comfortable home conditions and a relaxed state between classes. In general, students more often than schoolchildren note the advantages of distance learning, with advantages being identified by less than $10 \%$ of the student group. The results obtained are consistent with the studies [20,38,46-48], indicating that, in general, students perceive distance learning positively.

As for disadvantages to the distance form, students often note $(>50 \%)$ the difficulty of concentrating on studying at home, the lack of "live" communication with the teacher, the difficulty of performing practical tasks without an explanation from the teacher, the interference of relatives in the learning process in remote form; interruptions to the internet, power outages, the lack of "live" communication with classmates and the need to listen to tedious speech with text already in the presentation. Gunes [18] wrote about the 
students' preference for live communication. The presence of difficulties for students in performing practical tasks was also emphasized [16]. Students consider less significant disadvantages of distance learning $(<10 \%)$ to be a large amount of information for selfstudy. As compensatory mechanisms, it can be noted that in this case, students resort to manipulative techniques in teaching, for example, replacing creative work with texts from the internet and performing tasks with finding answers using a smartphone [49]. No student chose the items "insufficient knowledge of computer technology" and "partial assimilation of information".

Thus, it is of interest that the variety of choices among the student group both regarding advantages and disadvantages to distance learning is greater than in the group of secondary school students. Meanwhile, the leading advantage for schoolchildren and students is to reduce the chances of infection with coronavirus. The disadvantage of "the difficulty of performing practical tasks without the teacher's explanation" is underlined by both students and schoolchildren. However, the item "insufficient knowledge of computer technology" is not relevant in the group of students and schoolchildren.

It was found that students are more likely to have a positive attitude to distance learning than schoolchildren. This is also evidenced by the results of Elshansky's research, which revealed a positive attitude of students toward distance learning: students characterize it as "necessary, convenient and safe in this period, as well as quite effective, which allows them to gain the necessary knowledge and form professional competencies" [48].

In groups of students and schoolchildren, a number of advantages and disadvantages of distance learning differ. The visibility of slides and graphic material in the process of distance learning is more important for schoolchildren than for students. Other differences in frequency prevail in the group of students. The following advantages of distance learning are thus different and more significant for schoolchildren: reduction in fatigue from studying, absence of fear of oral answers, the flexibility of the educational process, that personal matters can be performed between classes, the ability independently to build a schedule, the ability to combine work with study, relaxed state of mind and body, fresh air, economic benefits, no transport costs and no lunch costs in the dining room. Students are more focused on independent time management, the ability to combine study with work and personal affairs and the economic benefits of distance learning; all these are also important for students. We can say that students are more ready for digitalization, new things and innovative activities generally, as confirmed by a number of studies [50].

The analysis of the disadvantages of distance learning, which are different in groups of students and schoolchildren, allows us to conclude that the disadvantages are more significant for schoolchildren than for students. These included the problem of replacing learning with self-study, a large amount of information for self-study, information being only partially assimilated and the load on vision. Secondary school students are more concerned about the educational process itself and the amount of material for self-study, as well as the load on the visual analyzer.

Other disadvantages that are different in groups of students and schoolchildren often prevail in the group of students. More significant for students are the following disadvantages to distance learning: internet interruptions, power outages, an insufficient amount of educational material, untimely presentation of educational material by the teacher, lack of "live" communication with the teacher, lack of "live" communication with classmates, no feedback in communication with the teacher, no feedback in communication with classmates, the need to listen to a tedious speech (the content of which repeats the text of the presentation), there being no one to ask questions to and poor concentration on the learning process at home. These characteristics, in particular, the need for live communication, are also indicated $[16,18,51,52]$. Students pay more attention to technical difficulties, a communicative deficit in teaching and an insufficient amount of educational material in distance learning. 


\section{Conclusions}

The study of the attitude to distance learning of schoolchildren and students allows us to draw a number of conclusions.

1. Despite the supposed ease of this method, and demonstration of the positive attitude among schoolchildren to distance learning, only 3.3\% are ready to continue their education in distance learning. That is, most schoolchildren accept distance learning as a necessity related to the prevention of the spread of a new coronavirus infection (COVID-19) and not as a preferred form of education;

2. Schoolchildren are significantly more likely to note that the self-assessed motivation to study in a distance format has not changed or decreased, and the volume of the academic load has not changed or increased. Students, on the other hand, coincide with schoolchildren in assessing motivation but more often note that the academic load in the distance form has decreased;

3. The variety of choices, both advantages and disadvantages, of distance learning in the student group is greater than in the group of secondary school students. The leading advantage of distance learning for both schoolchildren and students is to reduce the chances of infection with coronavirus;

4. Students are more likely to have a positive attitude to distance learning than schoolchildren;

5. Students in distance learning are more focused on independent time management, the ability to combine study with work and personal affairs and the economic benefits of distance learning. Schoolchildren, meanwhile, are concerned about the accessible visibility of the graphic material for the training session;

6. Secondary school students are more concerned about the educational process itself and the amount of material for self-study, as well as the load on the visual analyzer. University students pay more attention to technical difficulties, communicative deficits in teaching and insufficient amounts of educational material in distance learning.

The prospective solutions to this problem are the study of psychological and pedagogical factors determining the positive and negative attitude to distance learning, both among students of secondary schools and at university. Moreover, a significant vector in the development of this topic is the study of the psychological determinants of the development of a positive or negative attitude towards distance learning, as well as the study of the role of specific means and methods when organizing the educational process.

These studies can be used by the methodological services of secondary schools and universities to draw up recommendations for organizing the educational process in a distance form.

\section{Patents}

The authors declare the absence of patents.

Author Contributions: Conceptualization, A.B. and Y.M.; Methodology, A.B. and Y.T.; Validation Y.T. and Y.M.; Formal analysis, Y.T.; Investigation, A.B. and Y.M.; Data Curation, Y.T.; Writing-original draft, Y.M. and Y.T.; Writing-review \& editing, A.B. and Y.M.; Visualization, Y.T.; Supervision, A.B. All authors have read and agreed to the published version of the manuscript.

Funding: This research received no external funding.

Institutional Review Board Statement: The study was conducted according to the guidelines of the Declaration of Helsinki and Research Ethics Committee of Russian Psychological Society, Russia.

Informed Consent Statement: Informed consent was obtained from all subjects involved in the study.

Data Availability Statement: The data presented in this study are available on request from the authors.

Acknowledgments: The authors are grateful to all participants in the research and colleagues for their support in the creation of this paper.

Conflicts of Interest: The authors declare no conflict of interest. 


\section{References}

1. World Health Organization (WHO). Timeline: WHO's COVID-19 Response. 2020. Available online: https:/ /www.who.int/ emergencies/diseases/novel-coronavirus-2019/interactive-timeline\#! (accessed on 18 December 2021).

2. Federal Law No. 273-FZ “On Education in the Russian Federation”: Adopted by the State Duma on December 2012 [Electronic Resource] / / Consultant Plus. Available online: http:/ / www.consultant.ru/cons / cgi/online.cgi?req=doc\&ts=uFIfNuS0kSilpunB2 \&cacheid=2ECB13A9BC613213CAB0F8B2B89DD534\&mode=splus\&base=LAW\&n=388568\#GdJfNuS02Dce3brn2 (accessed on 9 January 2022).

3. Grinberg, G. Distance Education Technologies: Best Practices for K-12. IEEE Technol. Soc. J. (Winter) 1998, 17, 36-40. [CrossRef]

4. Tister, P.; Blizner, R. The promises and pitfalls of interactive television's approach to adult learning development and aging. Educ. Gerontol. 1999, 25, 741-754. [CrossRef]

5. Keegan, D. Distance Training: Taking Stock at a Time of Change; Routledge: London, UK; New York, NY, USA, 2000. Available online: https:/ / archive.org/details/distancetraining0000keeg (accessed on 9 January 2022).

6. Zubov, A.V.; Zubova, I.I. Information Technologies in Linguistics; Publishing Center "Academy": Moscow, Russia, 2000.

7. Andreev, A.A.; Soldatkin, V.I. Distance-Learning: Essence, Technology, Organization; MESI Publishing House: Moscow, Russia, 1999. Available online: http:/ / window.edu.ru/resource/850/23850/files/book_3.pdf (accessed on 9 January 2022).

8. Inman, E.; Kerwin, M. The attitude of the teacher and students to distance-learning. J. Community Coll. Res. Pract. 1999, 23, 581-592. [CrossRef]

9. Narbut, N.P.; A Aleshkovski, I.; Gasparishvili, A.T.; Krukhmaleva, O.V. Forced shift to distance learning as an impetus to technological changes in the Russian higher education. Rudn. J. Sociol. 2020, 20, 611-621. [CrossRef]

10. Sherritt, S. A Fundamental Problem with Distance-Learning Programs in Higher Education. (Opinion Paper No. 120). Viewpoints. (ERIC Document Reproduction Service No. ED 389 906). 1996. Available online: https: / / eric.ed.gov / ?id=ED389906 (accessed on 9 January 2022).

11. Pleshakov, V.A.; Sklyarova, T.V. "Force majeure cyber pedagogy", or the extraordinary conditions of education of the COVID-19 era. Electron. Sci. J. Species Homo Cyberus. 2020, 1. Available online: http://journal.homocyberus.ru/Pleshakov_VA_Sklyarova_ TV_1_2020 (accessed on 9 January 2022).

12. Threlkeld, R.; Brzoska, K. Research in Distance Education. In Distance Education: Strategies and Tools; Willis, B., Ed.; Educational Technology Publications: Englewood Cliffs, NJ, USA, 1994.

13. DiBiase, D. Is Distance Education a Faustian Bargain? J. Geogr. High. Educ. 2000, 24, 130-135. [CrossRef]

14. McKnight, M. Distance-Learning: Expression of Emotions in Video Classes. Paper Presented at the Annual Meeting of the Conference on College Composition and Communication, Minneapolis, MN. (Eric Document Reproduction Service No. ED 441 270). Available online: https:/ / mpra.ub.uni-muenchen.de/id/eprint/57469 (accessed on 9 January 2022).

15. Alla, B.; Ekaterina, B. Gnostic emotions of students in solving of thinking tasks. Int. J. Cogn. Res. Sci. Eng. Educ. 2020, 8, 27-34. [CrossRef]

16. Gonçalves, S.P.; Sousa, M.J.; Pereira, F.S. Distance Learning Perceptions from Higher Education Students-The Case of Portugal. Educ. Sci. 2020, 10, 374. [CrossRef]

17. Dan, B.; Golan, C. Impact of Thinking Styles on Learning Functions in the Online Environment. Int. J. Infonomics 2014, 7, 891-897. [CrossRef]

18. Gunes, S. What are the perceptions of the students about asynchronous distance learning and blended learning? World J. Educ. Technol. Curr. Issues 2019, 11, 230-237. [CrossRef]

19. Petko, D.; Cantieni, A.; Prasse, D. Perceived Quality of Educational Technology Matters: Secondary analysis of the use of ICT by students, attitudes related to ICT, and PISA test results in 2012. J. Educ. Comput. Res. 2016, 54, 1070-1091. [CrossRef]

20. Stosic, L.; Dermendzhieva, S.; Tomczyk, L. Information and communication technologies as a source of education. World J. Educ. Technol. Curr. Issues 2020, 12, 128-135. [CrossRef]

21. Hinostroza, E.J. New ICT challenges in the educational policy of developing countries: The need to take into account the widespread use of ICT for teaching and learning outside of school. In Innovations Supported by ICT in Small Countries and Developing Regions. Educational Communications and Technologies: Problems and Innovations; Lyubin, I., Ed.; Springer: Cham, Switherland, 2018. [CrossRef]

22. Wang, Z.; Wang, J.; Haggerty, N. Why people benefit from e-learning: The influence of psychological processes on the results of e-learning. Inf. Manag. 2008, 45, 513-521. Available online: https://www.sciencedirect.com/science/article/pii/S0378720608001 043 (accessed on 9 January 2022).

23. Yashina, L.I.; Goreva, O.M. Problems of introduction of distance education in higher education. Bull. Surgut State Pedagog. Univ. 2019, 4, 84-90. [CrossRef]

24. Murzina, N.P. Professional readiness of teachers for distance-learning in a tense situation in society and education. Bulletin of Omsk State Pedagogical University. Humanit. Stud. 2020, 2, 152-156. [CrossRef]

25. Almazova, N.; Krylova, E.; Rubtsova, A.; Odinokaya, M. Challenges and Opportunities for Russian Higher Education amid COVID-19: Teachers' Perspective. Educ. Sci. 2020, 10, 368. [CrossRef]

26. Manohar, N.-N. The Influence of learning styles on learners in e-learning environment: An empirical study. Comput. Rev. High Educ. Econ. 2006, 18, 10-14. Available online: https://econpapers.repec.org/article/chechepap/v_3a18_3ay_3a2006_3ai_3a1_3 ap_3a10-14.htm (accessed on 9 January 2022). 
27. Gomez, A.; Santos, A.; Carmo, L.; Mendes, A.J. Learning Styles in an E-Learning Tool. In Proceedings of the International Conference on Engineering Education ICEE 2007, Coimbra, Portugal, 3-7 September 2007. Available online: http:/ / www.gecad. isep.ipp.pt/Gecad/Files/Publications/Publications/P_1118/Anabela_icee2007.pdf (accessed on 9 January 2022).

28. Banks, A.S.; Fowl, A.S. Reducing hours of personal communication in basic research courses: The impact on students' acquired knowledge and course satisfaction. Educ. Field Soc. Work 2007, 26, 780-793. [CrossRef]

29. Belousova, A.; Vyshkvyrkina, M.; Barsukova, O.; Krishchenko, E.; Mozgovaya, N.; Mochalova, J.; Pavlova, T.; Tushnova, J. Features of social intelligence of students of different nationalities. INTED2017 Proc. 2017, 3234-3241. [CrossRef]

30. Salomon, G. Technology and Education in the Age of Information; Haifa University and Zmora-Bitan: Haifa, Israel, 2000.

31. Allen, I.E.; Seaman, J. Advanced Training: Online Education in the United States; Sloan Consortium: Boston, MA, USA, 2018. Available online: https:/ / eric.ed.gov / ?Id=ED530101 (accessed on 9 January 2022).

32. Carey, J.M. Effective student outcomes: Comparison of online and face-to-face learning methods. Distance Educ. Online Symp. 2001, 11, 9. Available online: http://www.ed.psu.edu/ascde/deos/deosnews/deosarchives.asp (accessed on 9 January 2022).

33. Kavanaugh, M.A.; Milkovich, G.T.; Tan, J. Human and Technical Aspects of Multimedia Distance-Learning (LEI): A Study of the Effectiveness of Lei in the Global Class of Human Resource Management-A Working Paper; Cornell University: New York, NY, USA, 2000.

34. Chou, C.C. A model of computer-mediated student-centered interaction for collaborative distance-learning. Int. J. E-Learn. 2004, 3, 11-18. Available online: https://ir.stthomas.edu/celc_ed_te_pub/11/ (accessed on 9 January 2022).

35. Kauffman, H. A review of predictive factors of student success in and satisfaction with online learning. Res. Learn. Technol. 2015, 23, 26507. [CrossRef]

36. Wladis, C.; Conway, K.M.; Hachey, A.C. The Online STEM Classroom-Who Succeeds? An Exploration of the Impact of Ethnicity, Gender, and Non-traditional Student Characteristics in the Community College Context. Community Coll. Rev. 2015, 43, 142-164. [CrossRef]

37. Müller, A.M.; Goh, C.; Lim, L.Z.; Gao, X. COVID-19 Emergency eLearning and Beyond: Experiences and Perspectives of University Educators. Educ. Sci. 2021, 11, 19. [CrossRef]

38. Dubey, P.; Pandey, D. Distance-learning in Higher Education during Pandemic: Challenges and Opportunities. Int. J. Indian Psychol. 2020, 8, 43-46. [CrossRef]

39. Samorodova, E.A.; Belyaeva, I.G.; Bakaeva, S.A. Analysis of communicative methods effectiveness in teaching foreign languages during the coronavirus epidemic: Distance format. XLinguae 2021, 14, 131-140. [CrossRef]

40. Smith, J.; Guimond, F.-A.; Bergeron, J.; St-Amand, J.; Fitzpatrick, C.; Gagnon, M. Changes in Students' Achievement Motivation in the Context of the COVID-19 Pandemic: A Function of Extraversion/Introversion? Educ. Sci. 2021, 11, 30. [CrossRef]

41. Abou-Khalil, V.; Helou, S.; Khalifé, E.; Chen, M.; Majumdar, R.; Ogata, H. Emergency Online Learning in Low-Resource Settings: Effective Student Engagement Strategies. Educ. Sci. 2021, 11, 24. [CrossRef]

42. Sagin, G.A. Analysis of preliminary results of distance education during the COVID-19 pandemic: A student's view of the source of the problems that have arisen. Electron. Sci. J. Species Homo Cyberus 2020, 2. Available online: http://journal.homocyberus.ru/ Sagin_GA_2_2020 (accessed on 9 January 2022).

43. Kolesnikova, A.A.; Kolesnikov, O.L.; Yu Khudyakova, O.; Peshikov, O.V. Analysis of feedback data on the quality of education in conditions of self-isolation. Scientific review. Pedagog. Sci. 2020, 4, 32-36. [CrossRef]

44. Kolesnikova, A.A.; Kolesnikov, O.L.; Sinitsky, A.I.; Yu Shishkova, S. Assessment of Student Satisfaction in the Conditions of Distance Education. Mod. Probl. Sci. Educ. 2020, 4. Available online: https://science-education.ru/ru/article/view?id=30068 (accessed on 18 December 2021).

45. Ryabikina, Z.; Ozhigova, L.; Barysheva, N.; Lupenko, N. Communication and motivation for success in distance-learning. In XIV International Scientific Conference "INTERAGROMASH 2021"; Lecture Notes on Networks and Systems; Beskopylny, A., Shamtsyan, M., Eds.; Springer: Cham, Switherland, 2022; Volume 247, pp. 447-455. [CrossRef]

46. Pronenko, E.; Tsakhilova, K.; Popova, D.; Belikova, M. Teachers and students in the digital age: Attitude to online learning, analysis of aspects of communication and transmission of meaning. In XIV International Scientific Conference "INTERAGROMASH 2021"; Lecture Notes on Networks and Systems; Beskopylny, A., Shamtsyan, M., Eds.; Springer: Cham, Switherland, 2022; Volume 247, pp. 563-577. [CrossRef]

47. Selco, J.I.; Habbak, M. STEM Students' Perceptions on Emergency Online Learning during the COVID-19 Pandemic: Challenges and Successes. Educ. Sci. 2021, 11, 799. [CrossRef]

48. Elshansky, S.P.; Ferapontova, M.V.; Efimova, O.S. Students' attitude to distance-learning during the pandemic: Positive and negative aspects. Pedagog. Psychol. Educ. 2021, 2, 125-136. [CrossRef]

49. Efremova, O.; Kobysheva, L.; Shalova, S. Manipulative techniques of students during certification in distance-learning. In XIV International Scientific Conference "INTERAGROMASH 2021"; Lecture Notes on Networks and Systems; Beskopylny, A., Shamtsyan, M., Eds.; Springer: Cham, Switherland, 2022; Volume 247, pp. 407-415. [CrossRef]

50. Kozhukhar, G.; Belousova, A.; Breus, E. Attitudes in the motivational sphere and Change readiness of university students. E3S Web Conf. 2020, 210, 18009. [CrossRef] 
51. Abakumova, I.; Bakaeva, I.; Grishina, A.; Dyakova, E. Active learning technologies in distance education of gifted students. Int. J. Cogn. Res. Sci. Eng. Educ. 2019, 7, 85-94. [CrossRef]

52. Novkovich Tsvetkovich, B.; Stosic, L.; Belousova, A. Media and information literacy-The basis for the use of digital technologies in teachers from the obra discourse [Media and information literacy-The basis for the use of digital technologies in teaching from the point of view of the educational needs of teachers]. Croat. J. Educ.-Croat. Chron. Odga Educ. 2018, 20, 1089-1114. [CrossRef] 